\title{
Dijital Oyun Kullanımı ve Aile İletişimi: Çanakkale'de Üniversitede Öğrencileri Üzerine Bir Araştırma
}

\author{
Usage of Digital Game and Family Communication: A Research on Unıversity Students in Canakkale
}

Ümit Demir, Dr. Öğr. Üyesi, Çanakkale Onsekiz Mart Üniversitesi, E-posta: umitdemir@comu.edu.tr

https://doi.org/10.47998/ikad.951769

Anahtar Kelimeler:

Dijital Oyun, Mobil Oyun, Aile İletişimi.

Keywords:

Digital Game, Mobile Game, Family

Communication.

\section{$\ddot{O} z$}

Pandemi süreci ile birlikte sosyal ağlar gibi bilgisayar ve mobil ortamlarda dijital oyun kullanımı artış göstermiştir. Bu dijital platformların yoğun kullanımının, kişilerarası iletişimde ne tür etkileri olabileceği tartışma konusu olmaktadır. Dijital oyun ortamlarının etkilediği sosyal iletişim ortamlarından birisinin de; aile iletişim ortamı olduğu düşünülmektedir. Bu çalışmada, üniversite öğrencilerinin dijital oyun ortamlarını kullanım durumlarına göre, dijital oyun aile iletişim puanlarının farklılaşma durumu incelenmiştir. Araştırmanın çalışma kümesini, 2020-2021 Bahar döneminde Çanakkale Onsekiz Mart Üniversitesi'nde farklı bölümlerde öğrenimlerine devam etmekte olan 301 öğrenci oluşturmaktadır. Araştırma kapsamında araştırmacı tarafından geliştirilen "Dijital Oyun Kullanımı ve Aile İletişim” ölçeği kullanılmıştır. Ölçeğin iç tutarlılık belirlenmesinde tüm maddeleri için Cronbach alfa güvenilirlik katsayıs1; 0.887 olarak hesaplanmıştır. Toplam 3 faktör ve 16 maddeden oluşan ölçekte faktörler, toplam varyansın \%58.783'ünü açıklamaktadır. Verilerin çözümlenmesi sürecinde, betimsel istatistik çözümleme yöntemleri kullanılmıştır. Araştırmada sonuç olarak; cinsiyet, bilgisayar ve bilgisayar kullanım sürelerine göre dijital oyun aile iletişim puanlarında anlamlı farklılıklar saptanmıştır. Mobil telefon kullanım ve mobil oyun oynama sürelerine göre ise; dijital oyun aile iletişim puanlarında anlamlı bir farklılık bulunamamıştır.

\section{Abstract}

Along with the pandemic process, usage of digital games in computer and mobile environments has also increased, such as social networks. What kind of effects the intensive use of these digital platforms can have on interpersonal communication is a matter of debate. It is thought that one of the social communication environments thought to be affected by digital game environments is the family communication environment. In this study, the differentiation status of the scores of digital game family communication according to the level of use of digital game environments by university students was investigated. The study set of the study consists of 301 students who continue their education in different departments at Çanakkale Onsekiz Mart University in the 2020-2021 Spring semester. Within the scope of the research, the "Digital Game Use and Family Communication" scale developed by the researcher was used. In determining the scale's internal consistency, Cronbach's alpha reliability coefficient was calculated as 0.887 for all items of the scale. In the scale, which consists of a total of 3 factors and 16 items, the factors explained $58.783 \%$ of the total variance. Descriptive statistical analysis methods were used in the analysis of the data. As a result of the study, significant differences were found in digital game and family communication scores according to gender, computer and computer usage time. There were no significant differences in digital game and family communication scores according to mobile phone usage and mobile game playing times. 


\section{Giriș}

Oyun, oldukça eski bir kavram olarak eğlenme, zevk alma, rekabet, yarışma, temsil, iyi vakit geçirme gibi güdü ve davranışları gösteren bir eylemdir (Çavuş ve ark., 2016). Teknolojideki gelişmeler ile günümüz oyun anlayışı da değişkenlik göstermiş ve dijital oyun kavramı ortaya çıkarmıştır (Ülker ve ark., 2017). Dijital oyunlar; internete bağlı (çevrimiçi) olarak ya da bağlı olmadan (çevrimdışı) bilgisayar ve akıllı telefon gibi cihazlar ile oynanan oyunlardır (Gülbetekin ve ark., 2021). Bilgisayar teknolojilerindeki hızlı gelişmeler, bu alanda geliştirilen yazılımların da görsel kalitesini arttırmayı sağlamıştır. 3 Modelleme ve tasarım özelliklerini kullanan birçok sektör de bu gelişmeden etkilenmiştir. Dijital oyun platformları da bu gelişmeden etkilenen alanlar arasındadır. Günümüzde 2 boyutlu oyunlardan, 3 boyutlu uygulamalar içeren sanal ve artırılmış gerçeklik uygulamalarına geçiş sağlanmıştır. Oyunlarda sağlanan gerçekliğe yakın ses ve görsel animasyonlar, oyunlara olan ilgide ve oynama sürelerinde artışa neden olmuştur. Bu yoğun kullanım durumu da, bağımlılık kavramını ön plana taşımıştır.

Bağımlılık bir kişiye, nesneye veya maddeye aşırı düşkün olma hali, kontrol edilemez istek duyma olarak tanımlanmaktadır (Çelik, 2018). Maddeye duyulan bu düşkünlüğün ve istek düzeyinin normalin üzerine çıkması durumunda çeşitli işlev bozukluklarının oluşması, bağımlılığın en önemli göstergesi olarak ifade edilmektedir (Çavuş ve ark., 2016). Bu yüzden birey bağımlı hale geldiği nesneyi bırakmakta sorun yaşayabilmekte, sürekli onunla ilgilenme ve düşünme isteği duyabilmektedir (Horzum, 2011). Benzer şekilde oyun oynama güdüsünün ve hissedilen ihtiyacın dijital şekilde kontrolsüz olarak karşılanması, oyun bağımlılığını ortaya çıkarmaktadır (Ayas ve Horzum, 2017). Oyun bağımlılığı sonucunda, bireyde farklı fiziksel ve duygusal tepkiler meydana gelebilmektedir. Oyun bağımlılığı ile ilgili birey tepkilerinin tanımlanmasında ilk ölçüt belirleme çalışması olarak kabul edilen Griffiths (2008)'e göre; dikkat çekme, duygu değişikliği, tolerans, yoksunluk belirtileri, çatışma ve tekrarlama ölçütler olarak tanımlanmıştır. Dijital oyun oynayıcılarının bu platformları kullanmalarının temelinde; sosyalleşme, öz güven, yeterlik gibi çok sayıda psikolojik ihtiyaçlar bulunabilmektedir (Gülbetekin ve ark., 2021). Pandemi süreci ile sosyalleşmede yaşanan büyük sorunlar, dijital oyun ortamlarına yönlenmeyi arttırarak daha büyük sorun haline gelmiştir. Dijital oyun bağımlığı kullanıcılarda; hareketsizlik ve buna bağlı obezite, beceri bozukluğu, göz bozukluğu, baş ağrısı, saldırgan davranış, anti-sosyallik, şiddet eğilimi gibi birçok fiziksel ve psikolojik olumsuzluk yaşanmasına neden olabilmektedir (Horzum, 2011). Dijital oyun bağımlılığının yol açtığ 1 etkilere yönelik farklı çalışmalar bulunmaktadır. Gülbetekin ve ark. (2021) gerçekleştirmiş oldukları çalışma sonucunda dijital oyun bağımlılığının zayıf düzeyde de olsa fiziksel aktivite düzeyini olumsuz yönde etkilediği belirlenmiştir.

İnsanlar sosyal varlıklar olarak iletişim ve etkileşim kapsamında duygu ve düşünce aktarımı ihtiyacı duymaktadır (Karaçor ve Şahin, 2004). Sosyal medya ve dijital oyun gibi medya ortamları, kurumların ve yetişkinlerin kural, değer ve tutumlarını esneten, hatta bazı durumlarda ortadan kaldıran yeni bir sosyalleşme alanı ortaya çıkarmıştır. $\mathrm{Bu}$ sosyal ortamda çocuklar ve ergenler de yetişkinlerin izleyebileceği şiddet, cinsellik ya da argo söz içerikli görüntü veya sözlere, kolayca erişebilmektedir (Özkan ve Hira, 2017). Aile ortamları çocukların ve bireylerin ihtiyaçlarını karşıladıkları ve sevgi gibi 
manevi doyumu yaşadıkları en doğal ortamdır (Usta, 2019). Sağlıklı bir anne baba ve çocuk bağının oluşumunda, çocuğun duygusal sağlığı açısından anne babanın çocukla sosyal etkileşim halinde hoşgörülü, dengeli ve sağlıklı tutum geliştirmesi önemlidir Sosyal medya gibi dijital ekran uygulamalarına yönelik uygulamalar, aile bağlarını zayıflatabilmektedir (Güleç, 2018). Ailelerin ve çocukların medya okuryazarlığına yönelik eğitim almadıkları veya yetersiz eğitim aldıkları durumlarda, bu ortamın etkisi giderek artabilmektedir. Ayrıca, gençlerin ve çocukların dijital aile ile iletişimlerine de olumsuz etkileri olabilmektedir. Bu alanda yapılan çalışmaların, sosyal medya kullanımı ağırlıklı olduğu görülmektedir (Demir, 2016; Dilber, 2019; Okumuş ve Parlar, 2018). Yoğun sosyal medya kullanımının etkileri üzerine gerçekleştirilen çalışmalarda Demir (2016) lise öğrencilerinin, Dilber (2019) üniversite öğrencilerinin Okumuş ve Parlar (2018) ise ortaokul öğrencilerinin, aile iletişimlerinin olumsuz yönde etkilendiği sonucuna ulaşmışlardır. Tersi bir ifadenin yani aile yapısının dijital ortam bağımlılığını etkilediğine yönelik çalışmalar da bulunmaktadır (Ni ve ark., 2009; Turan, 2015). Ni ve ark. (2009)'ın çalışmasında tek ebeveyni olan ergenlerde, Turan (2015)' in çalışmasında ise, anne-baba birlikteliği olmayan (boşanmış veya dul) öğrencilerin internet bağımlılığının yüksek olduğu belirlenmiştir.

Dijitaloyunkullanımınailişkinaileiçerikliulusaldüzeydearaştırmalarincelendiğinde, çalışmaların çoğunluğunun dijital oyun kullanım ile aile davranış türü (otoriter, demokratik, ilgisiz vb.) arasındaki ilişkiyi sorgulayan çalışmalar olduğu görülmektedir (Bonnaire ve Phan,2017; Eni, 2017; Karacaoğlu, 2019; Kwon ve ark., 2015; Yiğit ve Günüç, 2020; Zhu ve ark., 2015). Yiğit ve Günüç (2020) tarafından yürütülen çalışmada (ortaokul 5.,6., 7., 8. Sınıf öğrencileri) dijital oyun bağımlısı olarak tanımlanan çocukların, ebeveynlerinden az ilgi gördükleri, onların kendileri ile iletişimde güçlükler yaşadıkları ve bazılarının ebeveynlerinden hafif veya ağır şiddete maruz kaldıkları belirtmiştir. Aynı çalışmada çocukları dijital oyun bağımlısı olmayan ailelerin; geniş aile yapısına sahip, huzurlu bir ortam ve aile içerisinde yasaklar koymak yerine sınırların belirlendiği görülmüştür. Karacaoğlu'da (2019) aile yapısı ile dijital oyun bağımlılığı arasındaki ilişki taraması alanında yaptığı çalışma sonucunda; dijital oyun bağımlığının anne baba tutumuna göre anlamlı bir şekilde farklılaştığı sonucuna ulaşmıştır. Koruyucu/kollayıcı anne baba tutumuna sahip olan çocukların, ilgili/hoşgörülü anne baba tutumuna sahip olan çocuklara kıyasla daha fazla bilgisayar oyun bağımlısı olduğu da bu çalışmada görülmüştür. Eni (2017)' de benzer şekilde demokratik ebeveyn tutumu ile dijital oyun bağımlılığı arasında negatif ilişki saptamıştır. Uluslararası çalışmalarda da benzer sonuçlar bulunmaktadır. Bonnaire ve Phan (2017), 437 ergen katılımcı ile gerçekleştirdiği çalışma sonucunda anne baba tutumlarının oyun bağımlılığı üzerinde yordayıcı (zayıf aile bağı yüksek dijital oyun bağımlılığ 1 , yüksek aile bağı düşük oyun bağımlığı) etkisi olduğu sonucuna ulaşmıştır. Kwon ve ark. (2011) tarafından gerçekleştirilen bir başka araştırmada; ergen çocuklarının yaptıkları etkinlikleri görmezden gelen ve yok sayan, çocuklara baskı yapan ve düşmanca davranan ebeveynler gibi, olumsuz aile içi ilişkilerde çocukların internet oyunlarına harcadıkları zamanın da artış gösterdiği sonucuna ulaşmıştır. Zhu ve ark. (2015)'da anne, baba, ergen ilişkisinin olumlu olmasının, oyun bağımlılığını azaltmada fayda sağladığı sonucuna ulaşmışlardır. Belirtilen ulusal ve uluslararası çalışmalar, aile özelliğinin dijital oyun oynama süresi ile ilişki olduğu yönünde çalışmadır. Dijital oyun kullanımının, aile 
iletişimine etkileri kapsamında ne tür anne baba ve genç iletişim davranışlarına, yani aile içi iletişim boyutuna etkisine yönelik halihazırda bir çalışmaya ulaşılamamıştır. $\mathrm{Bu}$ çalışma ile aile iletişiminin farklı boyutları alt maddeler ile incelerek, ne tür davranışlara yol açabildiği incelenecektir. Böylece dijital oyun bağımlılığına ilişkin anlamlı farklılık belirten ergen davranışlarının tespiti gerçekleştirilecektir. Literatürde pandemi süreci ile dijital ekran uygulamalarının kullanımının arttığı dönemde, ailelerin dijital oyun ortamlarında zaman kontrolünü çocuklarına bıraktıkları, bu nedenle kontrollerinin olmadığı ve dijital oyun bağımlılığına yönelik uzman talebinde de bulunmadıklarına yönelik çalışmalar bulunmaktadır (Toran ve ark., 2016). Çalışma kapsamında gençlerin bilgisayar, mobil telefon ve dijital oyun kullanım süreleri, oynadıkları oyunlara ilişkin elde edilen bilgiler verilerek, bu verilere göre aile iletişimlerinin farklılaşma durumu incelenmektedir. Bu sayede dijital oyun bağımlılığının aile iletişiminde sorun oluşturduğu belirlenen boyutları belirlenerek, çalışmanın dijital oyun bağımlılığının tanımlanmasının amaçlandığ çalışmalara katkı sağlaması ve ilerleyen süreçte yapılacak olan araştırmalara farklı bir bakış açısı kazandırması hedeflenmektedir. Ayrıca araştırma kapsamında, dijital oyun ve aile iletişimi ölçeği geliştirilmiştir. Bu ölçeğin dijital oyun ve aile iletişimine ilişkin farklı örneklemler üzerinde yapılacak araştırmalar için yardımcı bir tanılama aracı olarak kullanılabileceği düşünülmektedir. Araştırma kapsamında belirlenen problem ve alt problemler şöyledir:

\section{Araştırma Problemi ve Alt Problemler}

Araştırma problemi "Üniversite öğrencilerinin dijital oyun kullanım düzeyi aile iletişimini etkilemekte midir?" Problemin yanıtlanmasında aşağıda tanımlanan alt problemler belirlenmiştir:

1) Üniversite öğrencilerin dijital oyun oynama durumları nasıldır?

2) Kişisel özelliklerine göre üniversite öğrencilerinin dijital oyun aile iletişim puanları farklılık göstermekte midir?

3) Dijital oyun tercihlerine göre üniversite öğrencilerinin dijital oyun aile iletişim puanları farkl1lık göstermekte midir?

\section{Yöntem}

$\mathrm{Bu}$ araştırmada üniversite öğrencilerinin dijital oyun kullanım düzeylerine göre aile iletişiminin farklılaşma durumunun belirlenmesi amaçlandığından, betimsel tarama modeli kullanılmıştır. Tarama modeli; geçmişte ya da halihazırda mevcut olan bir durumun var olduğu şekliyle betimlemesinin yani tanımlanmasının amaçlandığı bir araştırma yaklaşımıdır (Karasar, 2007).

\section{1. Örneklem}

$\mathrm{Bu}$ çalışma; Çanakkale Onsekiz Mart Üniversitesi'nde lisans ve önlisans seviyesinde öğrenimlerinde devam etmekte olan 301 öğrencinin gönüllük esası ile araştırmaya katılımı neticesinde gerçekleştirilmiştir. Örneklem grubuna yönelik özellikler 
incelendiğinde (Tablo 1); katılımcıların \%32,6'sının kadın, \%67,6's1 ise erkek olduğu görülmektedir. Katılımcılardan kişisel bilgisayara (PC) sahip olanların oranı; \%94'tür. 5 saat ve üzeri günlük PC kullanan katılımcı oranı; \%52,9' dur. PC kullanım önceliği olarak ilk sırada; ders/ödev/araştırma $(\% 37,6)$ yer alırken, onu oyun $(\% 25,9)$, sosyal medya $(\% 23,9)$ ve film/dizi $(\% 12,6)$ takip etmektedir. Mobil telefon günlük kullanım süresinde ise katılımcılardan 5 saat ve üzeri mobil telefon kullanan katılımcıların oranı; \%28,3'tür. Mobil telefon kullanım önceliğinde; ilk sırada sesli/görüntülü görüşme $(\% 33,2)$ yer alırken, onu sosyal medya $(\% 30,9)$ ve oyun $(\% 30,2)$ takip etmektedir.

Tablo 1. Katılımcıların Kişisel Özelliklerine Göre Dağılımı

\begin{tabular}{|c|c|c|}
\hline Cinsiyet & $\mathrm{f}$ & $\%$ \\
\hline Kadın & 98 & 32,6 \\
\hline Erkek & 203 & 67,6 \\
\hline Kişisel PC & $\mathrm{f}$ & $\%$ \\
\hline Var & 283 & 94,0 \\
\hline Yok & 18 & 6,0 \\
\hline Günlük PC Kullanım Süre & $\mathrm{f}$ & $\%$ \\
\hline 1 saatten az & 33 & 11,0 \\
\hline 1-3 saat aras 1 & 59 & 19,6 \\
\hline 3-5 saat aras 1 & 50 & 16,6 \\
\hline 5-7 saat aras1 & 70 & 23,3 \\
\hline 7 saat ve üzeri & 89 & 29,6 \\
\hline \multicolumn{3}{|l|}{ PC Kullanım Önceliği } \\
\hline Eğitim (Ders/Ödev/Araştırma) & 113 & 37,6 \\
\hline Oyun & 78 & 25,9 \\
\hline Sosyal Medya & 72 & 23,9 \\
\hline Diğer (Film/Dizi) & 38 & 12,6 \\
\hline \multicolumn{3}{|l|}{ Mobil Telefon Kullanım Süre } \\
\hline 1 saatten az & 41 & 13,6 \\
\hline $1-3$ saat aras 1 & 96 & 31,9 \\
\hline $3-5$ saat aras 1 & 79 & 26,2 \\
\hline 5-7 saat aras 1 & 55 & 18,3 \\
\hline 7 saat ve üzeri & 30 & 10,0 \\
\hline Mobil Telefon Kullanım Önceliği & $\mathrm{f}$ & $\%$ \\
\hline Sesli/Görüntülü görüşme & 100 & 33,2 \\
\hline Oyun & 91 & 30,2 \\
\hline Sosyal Medya & 93 & 30,9 \\
\hline Diğer (Dizi/Film/Müzik) & 17 & 5,7 \\
\hline Toplam & 301 & 100 \\
\hline
\end{tabular}

\section{2. İşlem}

Araştırma kapsamında öğrencilerin dijital oyun kullanım düzeylerine göre aile iletişim durumlarının farklılaşma durumunu belirlemek amacıyla araştırmacı tarafından bir ölçek geliştirilmiştir. Ölçek maddelerinin hazırlanma sürecinde 45 üniversite öğrencisi 
ile online görüşme yapılarak, dijital oyun ortamları hakkında kişisel tecrübelerine dayalı aile iletişim sorunları hakkında açık uçlu sorular ile fikirlerine başvurulmuştur. Alınan görüşlerden benzer ifadeler tek bir maddeye dönüştürülerek, 5'li likert olarak ölçek formu geliştirilmiştir. Araştırma kapsamında Çanakkale Onsekiz Mart Üniversitesi Etik Kurulu'ndan izin alınarak, gönüllü katılım esası ile ölçek uygulamasına geçilmiştir. Ölçek uygulamasına katılım pandemi süreci nedeniyle Google Forms üzerinden online olarak gerçekleştirilmiştir. Ölçeğe ait Cronbach $\alpha$ güvenilirlik katsayısı 0,887 olarak belirlenmiştir. Toplam 16 madde içeren ölçek, 3 faktörden (iletişim tercihleri ve yalnızlık durumu, özgürlük ve eğlence, eleştiri/tartışma başlıkları) oluşmakta ve faktörler toplam varyansın \%58.783'ünü açıklamaktadır. Örneklem yeterliliğinin belirlenmesi için uygulanan KMO testi sonucu; 0,877 bulunmuştur. Ölçeğin 3 faktörüne ait özdeğerler ile özdeğerlerin toplam varyansı açıklama oranı Tablo 2'de verilmiştir. Ölçeğe ait maddelerinin faktörlere göre dağılımları ve yükleri Tablo 3 'te listelenmiştir.

Tablo 2. Ölçek Faktörlerinin Varyans Açıklama Oranları

\begin{tabular}{cccc}
\hline Faktörler & Özdeğer & \% Varyans Açılkama & Kümülatif \% \\
\hline 1 & 6,120 & 38,250 & 38,250 \\
2 & 1,831 & 11,444 & 49,694 \\
3 & 1,454 & 9,089 & 58,783 \\
\hline
\end{tabular}

Tablo 3. Ölçek Maddeleri ve Maddelere Ait Faktör Yükleri

\begin{tabular}{|c|c|c|c|}
\hline Madde İçeriği & Faktör 1 & Faktör 2 & Faktör 3 \\
\hline $\begin{array}{l}\text { 1. İnternet oyun iletişim modüllerinde kendimi daha iyi ifade } \\
\text { edebiliyorum. }\end{array}$ & ,400 & 624 & 041 \\
\hline $\begin{array}{l}\text { 2. Özel sorun ve problemlerimi ailem yerine oyun arkadaşlarımla } \\
\text { paylaşmayı tercih ederim. }\end{array}$ & ,660 &,- 030 &,- 281 \\
\hline 3. Ailemle aynı ortamda hiç konuşmadığımız zamanlar oluyor. & ,602 &,- 268 &,- 438 \\
\hline 4. Oyun kullanım sıklığım aile içerisinde tartışma konusu oluyor. &, 590 &,- 240 & ,357 \\
\hline 5. Oyun ortamları güzel ve eğlenceli zaman geçirmemi sağlıyor. & ,305 & 699 &, 281 \\
\hline $\begin{array}{l}\text { 6. Oyun oynarken akşamları odamdan dışarıya çıkmadığım } \\
\text { zamanlar oluyor. }\end{array}$ & ,642 & 274 & ,288 \\
\hline $\begin{array}{l}\text { 7. Oyun ortamındaki arkadaşlarımdan aileme kıyasla daha fazla } \\
\text { görüș ve öneri alıyorum. }\end{array}$ & ,731 &, 185 &,- 145 \\
\hline $\begin{array}{l}\text { 8. Oyun ortamlarında zaman geçirmeyi, ailemle zaman geçirmeye } \\
\text { tercih ederim. }\end{array}$ & ,657 &, 115 &,- 154 \\
\hline 9. Oyun ortamlarında kendimi daha rahat ve özgür hissediyorum. & 605 & ,490 &,- 083 \\
\hline 10. Oyun ortamındaki arkadaşlarım bana daha fazla değer veriyor. & ,640 & 221 &,- 121 \\
\hline 11. Ailemle beraberken konuşacak konu bulmakta zorlanıyorum. &, 724 &,- 256 &,- 397 \\
\hline 12. Aile ortamında konuşulan konular beni çok sıkıyor. & ,644 &,- 155 &,- 361 \\
\hline $\begin{array}{l}\text { 13. Ailemle beraber zaman geçirirken bile oyun oynamaya devam } \\
\text { ediyorum. }\end{array}$ &, 588 &,- 088 &,- 008 \\
\hline $\begin{array}{l}\text { 14. Oyundan dolayı ailemden çok tembel ve isteksiz olduğuma dair } \\
\text { eleștiriler allyorum. }\end{array}$ & 659 &,- 399 & ,359 \\
\hline $\begin{array}{l}\text { 15. Oyun oynamadan dolayı sağlık sorunları yaşadığıma/ } \\
\text { yaşayacağıma dair ailemden eleştiriler alıyorum. }\end{array}$ &, 598 &,- 249 &, 516 \\
\hline $\begin{array}{l}\text { 16. Oyundan dolayı ailemden okula ve derslere odaklanma sorunu } \\
\text { yaşadığıma/yaşayacağıma dair eleştiriler alıyorum. }\end{array}$ & ,702 &,- 307 & ,377 \\
\hline
\end{tabular}




\section{3. Ölçme Araçları}

Dijital oyun kullanımının aile iletişimine etkisinin belirlemesi amaçlanan bu çalışmada geliştirilen form 2 bölümden oluşmaktadır. İlk bölümde katılımcılara ait demografik (yaş, cinsiyet, bilgisayar, mobil telefon, dijital oyun kullanım) bilgiler istenilmiştir. İkinci bölümde ise 5'li likert olarak geliştirilmiş, 16 maddeden oluşan dijital oyun ve aile iletişim ölçeği bulunmaktadır. Araştırmacı tarafından geliştirilen ölçeğe ait Cronbach $\alpha$ güvenilirlik katsayısi; 0,889'tur.

\subsection{Veri Analizi}

Araştırmada mevcut durumun tespit edilerek betimlenmesine yönelik olarak ilişkisel tarama modeli kullanılmıştır. Araştırmanın bağımsız değişkenleri; üniversite öğrencilerinin cinsiyet, bilgisayar, mobil cihaz ve bu cihazlarda dijital oyunları kullanım düzeyleridir. Araştırmanın bağımlı değişkeni ise; üniversite öğrencilerinin dijital oyun ve aile iletişim ölçeği puanlarıdır. Veriler normal dağılım gösterdiği için verilerin analizinde t testi, tek yönlü anova ve scheffe istatistiki çözümleme yöntemleri kullanılmıştır. Öğrencilerin dijital ortam (bilgisayar ve mobil telefon) ve dijital oyun kullanım durumları belirlenerek, bu özelliklerin dijital oyun aile iletişim ölçeği sonuçlarına göre farklılaşma durumu 0,05 düzeyinde istatistik analiz programı ile hesaplanmıştır.

\section{Bulgular}

Araştırmanın temel problemi; dijital oyun kullanımının aile iletişimine etkisini belirlemektedir. Bu problemin çözümü için öğrencilerin mobil ve PC tabanlı dijital oyun kullanım durumları ile geçirdikleri süreler ve kullanım sıklıkları alt problem olarak belirlenmiştir. Alt bölümlerde problemin çözümüne ilişkin belirlenen alt problemlere ilişkin bulgulara yer verilmiştir.

\section{1. Üniversite Öğrencilerinin Dijital Oyun Kullanım Durumunun İncelenmesi}

Üniversite öğrencilerinin PC tabanlı dijital oyun kullanma durumlarına göre dağılımları Tablo 4'te verilmiştir. Katılımcıların 62'si $(\% 20,6)$ herhangi bir PC tabanlı oyun kullanmadığını belirtirken, oyun oynayan grup içerisinde çoğunluğun (f=94) 1-3 saat arası oyun oynadığı belirlenmiştir. 5 saat ve üzeri PC tabanlı dijital oyun oynayanlar oran 1 ise $\% 7^{\prime}$ dir.

Tablo 4. Üniversite Öğrencilerinin PC Tabanlı Dijital Oyun Günlük Ortalama Oynama Süresi

\begin{tabular}{ccc}
\hline PC Oyun Süre & $\mathrm{f}$ & $\%$ \\
\hline Oynamiyorum & 62 & 20,6 \\
\hline 1 saatten az & 89 & 29,6 \\
\hline $1-3$ saat aras1 & 94 & 31,2 \\
\hline $3-5$ saat aras1 & 35 & 11,6 \\
\hline $5-7$ saat aras1 & 16 & 5,3 \\
\hline 7 saat ve üzeri & 5 & 1,7 \\
\hline Toplam & 301 & 100,0 \\
\hline
\end{tabular}


PC tabanlı oyun oynayan öğrencilerin cinsiyet durumuna göre dağglımları incelendiğ zaman (Tablo 5); kadınların \%55,1'i PC tabanlı oyun oynamadığını belirtirken, erkeklerde ise bu oran sadece \%3,9'tur. Kadınlardan oyun oynayanların oranı incelendiği zaman \%29,6'sı 1 saatten az oyun oynadığını belirtirken, erkeklerin \%43,3'ü 1-3 saat arası dijital oyun oynadıklarını belirtmişılerdir.

Tablo 5. Üniversite Öğrencilerinin PC Tabanlı Dijital Oyun Günlük Ortalama Oynama Süresinin Cinsiyete Göre Dağılımı

\begin{tabular}{|c|c|c|c|c|c|c|c|c|}
\hline \multirow[b]{2}{*}{ Cinsiyet } & \multirow[b]{2}{*}{$\mathrm{f} / \%$} & \multicolumn{7}{|c|}{ PC Oyun Kullanım Süresi } \\
\hline & & Oynamiyorum & 1 saatten az & 1-3 saat & 3-5 Saat & 5-7 Saat & $\begin{array}{c}7 \text { saat ve } \\
\text { üzeri }\end{array}$ & Toplam \\
\hline \multirow{2}{*}{ Kadın } & $\mathrm{f}$ & 54 & 29 & 6 & 5 & 4 & 0 & 98 \\
\hline & $\%$ & 55,1 & 29,6 & 6,1 & 5,1 & 4,1 & 0,0 & 100,0 \\
\hline \multirow{2}{*}{ Erkek } & $\mathrm{f}$ & 8 & 60 & 88 & 30 & 12 & 5 & 203 \\
\hline & $\%$ & 3,9 & 29,6 & 43,3 & 14,8 & 5,9 & 2,5 & 100,0 \\
\hline
\end{tabular}

Üniversite öğrencilerinin mobil dijital oyun kullanma durumlarına göre dağılımları Tablo 6' da verilmiştir. Katılımcıların 66'sı $(\% 21,9)$ herhangi bir mobil oyun oynamadığını belirtirken, oyun oynayan grup içerisinde çoğunluğun $(\% 67,8) 1$ saatten az oyun oynadığı belirlenmiştir.

Tablo 6. Üniversite Öğrencilerinin Mobil Dijital Oyun Günlük Ortalama Oynama Süresi

\begin{tabular}{ccc}
\hline PC Oyun Süre & $\mathrm{f}$ & $\%$ \\
\hline Oynamiyorum & 66 & 21,9 \\
\hline 1 saatten az & 204 & 67,8 \\
\hline $1-3$ saat aras1 & 24 & 8,0 \\
\hline $3-5$ saat aras1 & 7 & 2,3 \\
\hline Toplam & 301 & 100,0 \\
\hline
\end{tabular}

Mobil tabanlı oyun oynayan öğrencilerin cinsiyet durumuna göre dağılımları incelendiği zaman (Tablo 7); kadınların \%46,9'u mobil tabanlı oyun oynamadığını belirtirken, erkeklerde ise bu oran sadece \%9,9'tur. Kadınlardan oyun oynayanların dağılımları incelendiği zaman kadınların \%37,8'i erkeklerin \%82,3'ü 1-3 saat arası mobil oyun oynadıklarını belirtmişlerdir. 
Tablo 7. Üniversite Öğrencilerinin Mobil Dijital Oyun Günlük Ortalama Oynama Süresinin Cinsiyete Göre Dağılımı

\begin{tabular}{ccccccc}
\hline \multirow{2}{*}{ Cinsiyet } & \multirow{f}{f}{$\% \%$} & \multicolumn{5}{c}{ Mobil Oyun Oynama Süresi } \\
\cline { 2 - 7 } & & Oynamiyorum & 1 saatten az & $1-3$ saat & $3-5$ Saat & Toplam \\
\hline \multirow{2}{*}{ Kadın } & $\mathrm{f}$ & 46 & 37 & 11 & 4 & 98 \\
\cline { 2 - 7 } & $\%$ & 46,9 & 37,8 & 11,2 & 4,1 & 100,0 \\
\hline \multirow{2}{*}{ Erkek } & $\mathrm{f}$ & 20 & 167 & 13 & 3 & 203 \\
\cline { 2 - 7 } & $\%$ & 9,9 & 82,3 & 6,4 & 1,5 & 100,0 \\
\hline
\end{tabular}

Üniversite öğrencilerinin PC tabanlı oyun tercihlerinin dağılımları Tablo 8'de verilmiştir. Katılımcıların en fazla oynadıkları dijital oyunlar sırasıyla "Counter Strike" (\%36,5), "LoL" (\%33,6), "PUBG" (\%22,3) olmuştur. Dijital oyun tercihi sıralamasında "LoL" $(\% 16,6)$ oyunu ilk sirada gelirken, onu Counter Strike $(\% 12,6)$ ve PUBG $(\% 10,3)$ takip etmiştir.

Tablo 8. Üniversite Öğrencilerinin PC Tabanlı Dijital Oyun Tercih Listesi

\begin{tabular}{ccccc}
\hline \multirow{2}{*}{ Oyun Adi } & \multicolumn{2}{c}{ İlk Tercihi Olanlar } & \multicolumn{2}{c}{ Oyunu Oynayanlar } \\
\cline { 2 - 5 } & $\mathrm{f}$ & 16,6 & 101 & 33,6 \\
\hline LoL & 50 & 12,6 & 110 & 36,5 \\
\hline Counter Strike & 38 & 10,3 & 67 & 22,3 \\
\hline PUBG & 31 & 8 & 50 & 16,6 \\
\hline Mine Craft & 24 & 8 & 40 & 13,3 \\
\hline Dota 2 & 24 & 6,6 & 63 & 20,9 \\
\hline Grand Theft Auto & 20 & 6,6 & 59 & 19,6 \\
\hline FIFA & 20 & 5 & 51 & 16,9 \\
\hline Tom Clancys Rainbow & 15 & 5 & 47 & 15,6 \\
\hline GTA 5 & 15 & 100,0 & &
\end{tabular}

Cinsiyete göre üniversite öğrencilerinin oyun tercihlerinin dağılımları Tablo 9'da verilmiştir. Kadın katılımcıların oynadıkları ilk 3 oyun sırasıyla "LoL", "PUBG" ve "GTA5" olurken, erkek kat1lımciların ise "Counter Strike", "LoL" ve "Grand Theft Auto" olmuştur. 
Tablo 9. Üniversite Öğrencilerinin PC Dijital Oyun Tercih Listesinin Cinsiyete Göre Dağılımı

\begin{tabular}{ccccccc}
\hline \multirow{2}{*}{ Oyun Ad 1} & \multicolumn{2}{c}{ Kadın $(\mathrm{n}=98)$} & \multicolumn{2}{c}{ Erkek $(\mathrm{n}=203)$} & \multicolumn{2}{c}{ Toplam } \\
\cline { 2 - 7 } & $\mathrm{f}$ & $\%$ & $\mathrm{f}$ & $\%$ & $\mathrm{f}$ & $\%$ \\
\hline LoL & 16 & 15,8 & 85 & 84,2 & 101 & 100 \\
\hline Counter Strike & 12 & 10,9 & 98 & 89,1 & 110 & 100 \\
\hline PUBG & 16 & 10,3 & 51 & 67 & 67 & 100 \\
\hline Mine Craft & 9 & 18 & 41 & 82 & 50 & 100 \\
\hline Dota 2 & 7 & 17,5 & 33 & 82,5 & 40 & 100 \\
\hline Grand Theft Auto & 9 & 14,3 & 54 & 85,7 & 63 & 100 \\
\hline FIFA & 8 & 13,6 & 51 & 86,4 & 59 & 100 \\
\hline Tom Clancys Rainbow & 8 & 15,7 & 43 & 84,3 & 51 & 100 \\
\hline GTA 5 & 15 & 5 & 47 & 15,6 & 62 & 100 \\
\hline
\end{tabular}

Üniversite öğrencilerinin mobil tabanlı oyun tercihlerinin dağılımları Tablo 10' da verilmiştir. Katılımcıların en fazla oynadıkları mobil oyunlar "PUBG" (\%18,3), "LoL" $(\% 10,3)$, "Candy Crush" (\%8) ve "Clash" (\%8) olmuştur. Mobil oyun tercih siralamasında ilk sirada; "PUBG" $(\% 14,3)$ oyunu gelirken, onu "LoL" $(\% 7,3)$ ve "Clash Royale" $(\% 7)$ takip etmiştir.

Tablo 10. Üniversite Öğrencilerinin Mobil Dijital Oyun Tercih Listesi

\begin{tabular}{ccccc}
\hline \multirow{2}{*}{ Oyun Ad 1} & \multicolumn{2}{c}{ İlk Tercihi Olanlar } & \multicolumn{2}{c}{ Oyunu Oynayanlar } \\
\cline { 2 - 5 } & $\mathrm{f}$ & $\%$ & $\mathrm{f}$ & $\%$ \\
\hline PUBG & 43 & 14,3 & 55 & 18,3 \\
\hline LoL & 22 & 7,3 & 31 & 10,3 \\
\hline Clash Royale & 21 & 7 & 24 & 8 \\
\hline Candy Crush & 18 & 6 & 24 & 8 \\
\hline Kafa Topu 2 & 18 & 6 & 22 & 7,3 \\
\hline Among Us & 15 & 5 & 21 & 7 \\
\hline FIFA & 15 & 5 & 19 & 6,3
\end{tabular}

Cinsiyete göre üniversite öğrencilerinin oyun tercihlerinin dağılımları tablo 11'de verilmiştir. Kadın katılımcıların oynadıkları ilk 3 oyun sırasıyla; "PUBG" ( $\mathrm{f}=22)$, "Candy Crush" (f=10) ve "Among Us" / "Kafa Topu 2" / "LoL" ( $\mathrm{f}=8)$ olurken, erkek kat1lımciların ise "PUBG" ( $\mathrm{f}=55)$, LoL ( $\mathrm{f}=23)$ ve "Clash Royale" ( $\mathrm{f}=24)$ olmuştur. 
Tablo 11. Üniversite Öğrencilerinin Mobil Dijital Oyun Tercihlerinin Cinsiyete Göre Dağılımı

\begin{tabular}{ccccccc}
\hline \multirow{2}{*}{ Oyun Ad 1} & \multicolumn{2}{c}{ Kadın } & \multicolumn{2}{c}{ Erkek } & \multicolumn{2}{c}{ Toplam } \\
\cline { 2 - 7 } & $\mathrm{f}$ & $\%$ & $\mathrm{f}$ & $\%$ & $\mathrm{f}$ & $\%$ \\
\hline PUBG & 22 & 40 & 33 & 60 & 55 & 100 \\
\hline LoL & 8 & 25,8 & 23 & 74,2 & 31 & 100 \\
\hline Clash Royale & 4 & 16,7 & 20 & 83,3 & 24 & 100 \\
\hline Candy Crush & 10 & 41,7 & 14 & 58.3 & 24 & 100 \\
\hline Kafa Topu 2 & 8 & 36,4 & 14 & 63,6 & 22 & 100 \\
\hline Among Us & 8 & 38,1 & 13 & 61,9 & 21 & 100 \\
\hline FIFA & 6 & 31,6 & 13 & 68,4 & 19 & 100 \\
\hline
\end{tabular}

\section{2. Üniversite Öğrencilerinin Kişisel Özelliklerine Göre Dijital Oyun Aile İletişim Puanlarının Farklılaşma Durumunun İncelenmesi}

\subsubsection{Cinsiyete Göre Dijital Oyun Aile İletişim Puanlarının Farklılaşma Durumunun İcelenmesi}

Cinsiyete göre dijital oyun aile iletişim puanlarının farklılaşma durumuna ait bağımsız t-testi sonuçları Tablo 12'de verilmiştir. T-testi sonucuna göre; öğrencilerin dijital oyun aile iletişim puanlarında cinsiyet duruma göre anlamlı farklılık gösterdiği $[\mathrm{t}=-3,388 ; \mathrm{p}<0,001]$ bulunmuştur.

Tablo 12. Cinsiyet Durumuna Göre Öğrencilerin Dijital Oyun Aile İletişim Puanına İlişskin Bağımsız t-Testi Sonuçları

\begin{tabular}{ccccccc}
\hline Cinsiyet & N & $\mathbf{X}$ & sd & df & t & p \\
\hline Kadın & 98 & 33,286 & 12,186 & 299 & $-3,388$ & $0,001^{* * * *}$ \\
Erkek & 203 & 37,798 & 10,110 & & & \\
\hline
\end{tabular}

$(* \mathbf{p}<0,05 ; * * \mathbf{p}<0,01 ; * * * \mathbf{p}<0,001)$

Farkın anlamlı çıkmasına etkisi olan ölçek maddelerinin incelenmesi sonucunda cinsiyete göre farklılık gösteren ölçek maddeleri Tablo 13'te verilmiştir. Ölçeğe ait 1 ., 5., 6., 7., 9. ve 15. maddelerde cinsiyete göre farkl1lık olduğu görülmektedir. İlgili ölçek maddeleri incelendiği zaman erkek öğrencilerin ilgili maddelerde puan ortalamaların, kadın öğrencilerin ilgili maddelerde verdiği yanıtların ortalama puanından anlamlı düzeyde farklı olduğu görülmektedir. Erkek öğrencilerin puan ortalaması, kadın katılımcıların puan ortalamasından anlamlı seviyede yüksektir. İlgili maddelere göre erkek katılımcılar kadın katılımcılara göre internet oyun iletişim modülünde kendilerini daha iyi ifade edebildiklerini (M1), dijital oyun ortamlarının güzel ve eğlenceli zaman geçirmelerini sağladığını (M5), dijital oyun sürecinde akşamları odalarından çıkmadıkları zamanlar olduğunu (M6), oyun ortamlarındaki arkadaşlarından ailelerine kıyasla daha fazla görüş ve öneri aldıklarını (M7), oyun ortamlarında kendilerini daha rahat ve özgür hissettiklerini (M9) ve ailelerinden oyun oynamadan dolayı sağlık sorunları yaşayacaklarına dair eleştiriler aldıklarını daha fazla oranda belirtmişlerdir. 
Tablo 13. Cinsiyet Durumuna Göre Öğrencilerin Dijital Oyun Kullanımı ve Aile İletişimi Ölçeğinde Anlamlı Farklılık Gösterdiği Maddelere İlişkin Bağımsız t-Testi Sonuçları

\begin{tabular}{|c|c|c|c|c|c|c|c|}
\hline Madde No & Cinsiyet & $\mathbf{N}$ & $\mathbf{X}$ & sd & Df & $\mathbf{t}$ & $\mathbf{p}$ \\
\hline \multirow{2}{*}{1} & Kadın & 98 & 33,2857 & 12,18585 & 299 & $-3,388$ & $0,000 * * *$ \\
\hline & Erkek & 203 & 37,7980 & 10,11046 & & & \\
\hline \multirow{2}{*}{5} & Kadın & 98 & 3,2755 & 1,24172 & 299 & $-6,398$ & $0,000 * * *$ \\
\hline & Erkek & 203 & 4,0493 & .83104 & & & \\
\hline \multirow[t]{2}{*}{6} & Kadın & 98 & 2,0612 & 1,36084 & 299 & $-4,403$ & $0,000 * * *$ \\
\hline & Erkek & 203 & 2,7488 & 1,22310 & & & \\
\hline \multirow{2}{*}{7} & Kadın & 98 & 1,6939 & 1,03951 & 299 & $-3,594$ & $0,000 * * *$ \\
\hline & Erkek & 203 & 2,1675 & 1,08615 & & & \\
\hline \multirow[t]{2}{*}{9} & Kadın & 98 & 2,2857 & 1,12149 & 299 & $-4,787$ & $0,000 * * *$ \\
\hline & Erkek & 203 & 2,9901 & 1,23075 & & & \\
\hline \multirow[t]{2}{*}{15} & Kadın & 98 & 1,9388 & 1,19117 & 299 & $-1,981$ & $0,049^{*}$ \\
\hline & Erkek & 203 & 2,2315 & 1,20666 & & & \\
\hline
\end{tabular}

$(* \mathbf{p}<0.05, * * \mathbf{p}<0.01, * * * \mathbf{p}<0.001)$

\subsubsection{Günlük Bilgisayar Kullanım Süresine Göre Dijital Oyun Aile İletişim Puanlarının Farklılaşma Durumunun İncelenmesi}

Günlük bilgisayar kullanım süresine göre dijital oyun aile iletişim puanlarının değişimlerine ilişkin varyans analiz sonuçları Tablo 14'te verilmiştir. Tek yönlü anova testi sonucuna göre; öğrencilerin dijital oyun aile iletişim puanlarında günlük PC bilgisayar kullanım süresine göre anlamlı farklılık gösterdiği $[F(4-296)=4,338$; $p<0,01]$ bulunmuştur.

Tablo 14. Günlük PC Kulanım Süresine Göre Dijital Oyun Kullanımı ve Aile İletişim Ölçeği Puanlarının Tek Yönlü ANOVA Sonuçları

\begin{tabular}{cccccc}
\hline Varyansın Kaynă̆ı & Kareler Toplamı & sd & KO & F & p \\
\hline Gruplararası & 2015,783 & 4 & 503,946 & 4,338 & $0,002^{* *}$ \\
\hline Gruplariçi & 34382,656 & 296 & 116,158 & & \\
\hline Toplam & 36398,439 & 300 & & & \\
\hline
\end{tabular}

$(* \mathbf{p}<0,05 ; * * \mathbf{p}<0,01 ; * * * \mathbf{p}<0,001)$

Farkın kaynağının tespiti için kullanılan Scheffe Testi sonucunda (Tablo 15) günlük bilgisayar kullanım süresi 7 saat ve üzeri olanların, 1 saatten az ve 1-3 saat kullananlara göre olumsuz aile iletişimi puanlarının anlamlı düzeyde $(p<0,05)$ daha yüksek olduğu sonucuna ulaşılmıştır. 
Tablo 15. Günlük PC Kullanım Süresine Göre Öğrencilerin Dijital Oyun Aile İletişim Puan Ortalamaları Arasındaki Farklılığın Anlamlıı̆̆ına İlişkin Scheffe Testi Sonuçları

\begin{tabular}{|c|c|c|c|c|c|c|}
\hline \multirow{2}{*}{ Gruplar } & \multirow{2}{*}{ Gruplar } & \multirow{2}{*}{$\begin{array}{c}\text { Ortalamaların } \\
\text { Farkı }\end{array}$} & \multirow{2}{*}{$\begin{array}{c}\text { Standart } \\
\text { Hata }\end{array}$} & \multirow{2}{*}{$\mathbf{p}$} & \multicolumn{2}{|c|}{ \%95 Güven Aralığı } \\
\hline & & & & & Alt Sınır & Üst Sınır \\
\hline \multirow{4}{*}{$\begin{array}{c}1 \text { Saatten } \\
\text { Az }\end{array}$} & 1-3 saat & $-1,41$ & 2,34 & 0,99 & $-8,68$ & 5,85 \\
\hline & 3-5 saat & $-3,48$ & 2,42 & 0,72 & $-10,97$ & 4,01 \\
\hline & 5-7 saat & $-5,41$ & 2,28 & 0,23 & $-12,47$ & 1,64 \\
\hline & 7 saat ve üzeri & $-7,29 *$ & 2,20 & 0,03 & $-14,10$ & $-0,48$ \\
\hline \multirow{4}{*}{$1-3$ saat } & 1 saatten az & 1,41 & 2,34 & 0,99 & $-5,85$ & 8,68 \\
\hline & $3-5$ saat & $-2,07$ & 2,07 & 0,91 & $-8,49$ & 4,36 \\
\hline & 5-7 saat & $-4,00$ & 1,90 & 0,36 & $-9,90$ & 1,91 \\
\hline & 7 saat ve üzeri & $-5,87 *$ & 1,81 & 0,03 & $-11,48$ & $-0,27$ \\
\hline \multirow{4}{*}{ 3-5 saat } & 1 saatten az & 3,48 & 2,42 & 0,72 & $-4,01$ & 10,97 \\
\hline & 1-3 saat & 2,07 & 2,07 & 0,91 & $-4,36$ & 8,49 \\
\hline & $5-7$ saat & $-1,93$ & 2,00 & 0,92 & $-8,12$ & 4,25 \\
\hline & 7 saat ve üzeri & $-3,81$ & 1,90 & 0,41 & $-9,71$ & 2,10 \\
\hline \multirow{4}{*}{ 5-7 saat } & 1 saatten az & 5,41 & 2,28 & 0,23 & $-1,64$ & 12,47 \\
\hline & 1-3 saat & 4,00 & 1,90 & 0,36 & $-1,91$ & 9,90 \\
\hline & 3-5 saat & 1,93 & 2,00 & 0,92 & $-4,25$ & 8,12 \\
\hline & 7 saat ve üzeri & $-1,88$ & 1,72 & 0,88 & $-7,21$ & 3,46 \\
\hline \multirow{4}{*}{$\begin{array}{l}7 \text { saat ve } \\
\text { üzeri }\end{array}$} & 1 saatten az & $7,29 *$ & 2,20 &, 03 & 0,48 & 14,10 \\
\hline & 1-3 saat & $5,87^{*}$ & 1,81 &, 03 & 0,27 & 11,48 \\
\hline & 3-5 saat & 3,81 & 1,90 & ,41 & $-2,10$ & 9,71 \\
\hline & $5-7$ saat & 1,88 & 1,72 &, 88 & $-3,46$ & 7,21 \\
\hline
\end{tabular}

\subsubsection{Günlük Mobil Telefon Kullanım Süresine Göre Dijital Oyun Aile İletişim Puanlarının Farklılaşma Durumunun İncelenmesi}

Günlük mobil telefon kullanım süresine göre dijital oyun aile iletişim puanlarının değişimlerine ilişkin varyans analiz sonuçları Tablo 16'da verilmiştir. Tek yönlü anova testi sonucuna göre; öğrencilerin dijital oyun aile iletişim puanlarında günlük mobil telefon kullanım süresine göre anlamlı farklılık göstermediği $\left[\mathrm{F}_{(4-296)}=0,483 ; \mathrm{p}>0,05\right]$ bulunmuştur.

Tablo 16. Günlük Akıllı Telefon Kullanım Süresine Göre Dijital Oyun ve Aile İletişim Ölçeği Puanlarının Tek Yönlü ANOVA Sonuçları

\begin{tabular}{cccccc}
\hline Varyansın Kaynă̆ı & Kareler Toplamı & sd & KO & F & p \\
\hline Gruplararası & 236,002 & 4 & 59,001 & 0,483 & 0,748 \\
\hline Gruplariçi & 36162,436 & 296 & 122,170 & & \\
\hline Toplam & 36398,439 & 300 & & & \\
\hline
\end{tabular}

$\left({ }^{*} \mathbf{p}<0,05 ; * * \mathbf{p}<0,01 ; * * * \mathbf{p}<0,001\right)$ 
Bu alt bölümde cinsiyet, bilgisayar ve mobil telefon kullanım sürelerine göre dijital oyun ve aile iletişim puanlarının farklılaşma durumu incelenmiştir. Cinsiyet ve kişisel bilgisayar kullanım süresine göre dijital oyun ve aile iletişim puanlarının anlamlı farklılık gösterdiği, mobil telefon kullanım süresine göre ise anlamlı bir farklılık göstermediği sonucuna ulaşılmıştır.

\section{3. Üniversite Öğrencilerinin Dijital Oyun Tercihlerine Göre Dijital Oyun} Aile İletişim Puanlarının Farklılaşma Durumunun İncelenmesi

\subsubsection{Günlük Bilgisayar (PC) Oyunu Oynama Süresine Göre Dijital Oyun Aile İletişim Puanlarının Farklılaşma Durumunun İncelenmesi}

Günlük bilgisayar oyunu oynama süresine göre dijital oyun aile iletişim puanlarının değişimlerine ilişkin varyans analiz sonuçları Tablo 17'de verilmiştir. Tek yönlü Anova testi sonucuna göre; öğrencilerin dijital oyun aile iletişim puanlarında günlük bilgisayar oyunu oynama süresine göre anlamlı farklılık gösterdiği $\left[\mathrm{F}_{(5-295)}=5,414 ; \mathrm{p}<0,001\right]$ bulunmuştur.

Tablo 17. Günlük Bilgisayar Oyunu Oynama Süresine Göre Dijital Oyun Kullanımı ve Aile Ölçeği Puanlarının Tek Yönlü ANOVA Sonuçları

\begin{tabular}{cccccc}
\hline Varyansın Kaynağı & Kareler Toplamı & sd & KO & F & P \\
\hline Gruplararası & 3059,165 & 5 & 611,833 & 5,414 & $0,000^{* * *}$ \\
\hline Gruplariçi & 33339,273 & 295 & 113,014 & & \\
\hline Toplam & 36398,439 & 300 & & &
\end{tabular}

$(* \mathbf{p}<0,05 ; * * \mathbf{p}<0,01 ; * * * \mathbf{p}<0,001)$

Farkın kaynağının tespitinde kullanılan Scheffe Testi sonucunda (Tablo 18); bilgisayar oyunlarını günlük 1-3 saat kullanan öğrenciler ile 1 saatten az kullanan öğrenciler ile günlük 7 saat ve üzeri bilgisayar oyunu kullanan öğrenciler ile 1-3 saat arası kullanan öğrencilerin, dijital oyun aile iletişim puanları arasında anlamlı bir farkın $(\mathrm{p}<.05)$ olduğu bulunmuştur.

Tablo 18. Günlük PC Dijital Oyun Oynama Süresine Göre Öğrencilerin Dijital Oyun Aile İletişim Puan Ortalamaları Arasındaki Farklılığın Anlamlıı̆̆ına İlişkin Scheffe Testi Sonuçları

\begin{tabular}{|c|c|c|c|c|c|c|}
\hline \multirow{2}{*}{ Gruplar } & \multirow{2}{*}{ Gruplar } & \multirow{2}{*}{$\begin{array}{c}\text { Ortalamaların } \\
\text { Farkı }\end{array}$} & \multirow{2}{*}{$\begin{array}{l}\text { Standart } \\
\text { Hata }\end{array}$} & \multirow{2}{*}{$\mathbf{p}$} & \multicolumn{2}{|c|}{ \%95 Güven Aralığı } \\
\hline & & & & & Alt Sinır & Üst Sınır \\
\hline \multirow{5}{*}{ Hiç } & 1 saatten az & $-11,51$ & 4,89 & 0,35 & $-27,88$ & 4,85 \\
\hline & 1-3 saat & 4,43 & 1,74 & 0,26 & $-1,40$ & 10,26 \\
\hline & 3-5 saat & 2,36 & 1,57 & 0,81 & $-2,91$ & 7,62 \\
\hline & 5-7 saat & $-3,44$ & 2,11 & 0,75 & $-10,50$ & 3,61 \\
\hline & 7 saat ve üzeri & $-6,46$ & 2,88 & 0,41 & $-16,09$ & 3,17 \\
\hline
\end{tabular}




\begin{tabular}{|c|c|c|c|c|c|c|}
\hline \multirow{5}{*}{$\begin{array}{c}1 \text { saatten } \\
\text { az }\end{array}$} & Hiç & $-9,16$ & 4,88 & 0,62 & $-25,50$ & 7,19 \\
\hline & 1-3 saat & $7,87^{*}$ & 2,25 & 0,03 & 0,34 & 15,40 \\
\hline & 3-5 saat & 5,80 & 2,12 & 0,19 & $-1,31$ & 12,91 \\
\hline & 5-7 saat & 3,44 & 2,11 & 0,75 & $-3,61$ & 10,50 \\
\hline & 7 saat ve üzeri & $-3,01$ & 3,21 & 0,97 & $-13,76$ & 7,73 \\
\hline \multirow{5}{*}{$1-3$ saat } & Hiç & $-5,71$ & 5,08 & 0,94 & $-22,74$ & 11,31 \\
\hline & 1 saatten az & $10,89^{*}$ & 2,98 & 0,02 & 0,90 & 20,87 \\
\hline & 3-5 saat & 8,81 & 2,89 & 0,10 & $-0,86$ & 18,49 \\
\hline & 5-7 saat & 6,46 & 2,88 & 0,41 & $-3,17$ & 16,09 \\
\hline & 7 saat ve üzeri & 3,01 & 3,21 & 0,97 & $-7,73$ & 13,76 \\
\hline \multirow{5}{*}{ 3-5 saat } & Hiç & $-2,70$ & 5,45 & 1,00 & $-20,95$ & 15,55 \\
\hline & 1 saatten az & 13,59 & 4,94 & 0,19 & $-2,97$ & 30,14 \\
\hline & 1-3 saat & 11,51 & 4,89 & 0,35 & $-4,85$ & 27,88 \\
\hline & 5-7 saat & 9,16 & 4,88 & 0,62 & $-7,19$ & 25,50 \\
\hline & 7 saat ve üzeri & 5,71 & 5,08 & 0,94 & $-11,31$ & 22,74 \\
\hline \multirow{5}{*}{ 5-7 saat } & Hiç & 2,70 & 5,45 & 1,00 & $-15,55$ & 20,95 \\
\hline & 1 saatten az & $-11,51$ & 4,89 & 0,35 & $-27,88$ & 4,85 \\
\hline & 1-3 saat & 4,43 & 1,74 & 0,26 & $-1,40$ & 10,26 \\
\hline & 3-5 saat & 2,36 & 1,57 & 0,81 & $-2,91$ & 7,62 \\
\hline & 7 saat ve üzeri & $-3,44$ & 2,11 & 0,75 & $-10,50$ & 3,61 \\
\hline \multirow{5}{*}{$\begin{array}{c}7 \text { saat ve } \\
\text { üzeri }\end{array}$} & Hiç & $-6,46$ & 2,88 & 0,41 & $-16,09$ & 3,17 \\
\hline & 1 saatten az & $-9,16$ & 4,88 & 0,62 & $-25,50$ & 7,19 \\
\hline & 1-3 saat & $7,87^{*}$ & 2,25 & 0,03 & 0,34 & 15,40 \\
\hline & 3-5 saat & 5,80 & 2,12 & 0,19 & $-1,31$ & 12,91 \\
\hline & 5-7 saat & 3,44 & 2,11 & 0,75 & $-3,61$ & 10,50 \\
\hline
\end{tabular}

$\left(p^{*}<0,05\right)$

\subsubsection{Günlük Mobil Oyun Oynama Süresine Göre Dijital Oyun Aile Iletișim} Puanlarının Farklılaşma Durumunun İncelenmesi

Günlük mobil oyun oynama süresine göre dijital oyun aile iletişim puanlarının değişimlerine ilişkin varyans analiz sonuçları Tablo 19'ta verilmiştir. Tek yönlü Anova testi sonucuna göre; öğrencilerin dijital oyun aile iletişim puanlarında günlük mobil oyun oynama süresine göre anlamlı bir farklılık göstermediği $[F(3-297)=1,887 ; p>0,05]$ bulunmuştur.

Tablo 19. Mobil Oyun Oynama Süresine Göre Aile İçi İletişim Ölçeği Puanlarının Tek Yönlü ANOVA Sonuçları

\begin{tabular}{cccccc}
\hline Varyansın Kaynağı & Kareler Toplamı & sd & KO & F & p \\
\hline Gruplararası & 680,761 & 3 & 226,920 & 1,887 & 0,132 \\
\hline Gruplariçi & 35717,678 & 297 & 120,262 & & \\
\hline Toplam & 36398,439 & 300 & & & \\
\hline
\end{tabular}

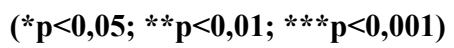


$\mathrm{Bu}$ alt bölümde, bilgisayar oyunu ve mobil oyun oynama süresine göre dijital oyun aile iletişim ölçeği puanları arasındaki ilişski sorgulanmıştır. Elde edilen analiz değerlerinde; bilgisayar oyunu kullanım süresine göre aile iletişim puanlarında anlamlı bir farklılık gösterdiği, mobil telefon oynama süresine göre ise anlamlı bir farklılık göstermediği sonucu elde edilmiştir.

\section{Tartışma ve Sonuç}

Dijital oyun kullanım pratiklerine göre aile iletişim durumlarının farklılaşmasına yönelik yapılan çalışma sonucunda birçok farklı boyuta ilişkin önemli bulgulara ulaşı1mıştır. Çalışmada neticesinde; aile iletişim durumlarının bilgisayar oyunu oynama süresine göre anlamlı farklılık gösterdiği ancak mobil oyun oynama süresine göre anlamlı bir farklılık göstermediği bulgusu elde edilmiştir. Ayrıca çalışmada elde edilen verilerle günlük PC kullanım süresine göre aile iletişim puanlarının anlamlı farklılık gösterdiği bulunurken, mobil telefon kullanım süresine göre ise anlamlı bir farklılık göstermediği bulgusu elde edilmiştir. Bilgisayar ve bilgisayar oyunu kullanımı durumlarında aile iletişim puanlarının anlamlı farklılık göstermesinde, bilgisayar kullanımı için ayrı bir ortam veya oda düzenlemesi gerekliliği etkili olmuş olabilir. Bu durum aile ile etkileşim kurma ihtimalini sınırlandırabilir. Mobil cihaz kullanımı için esneklik çok daha fazla olabilmektedir. Aile ortamı içerisinde mobil cihaz kullanımı, kişisel bilgisayara göre daha kolay olabilmektedir. Cihazlarda meydana gelen farkta bu etmenin etkili olabileceği düşünülmektedir.

Kişisel özelliklere göre dijital oyun ve aile iletişim puanlarının farklılaşma durumunun da incelendiği bu çalışmada, cinsiyet özelliğine göre anlamlı bir farklılık olduğu bulgusu elde edilmiştir. Erkek katılımcıların dijital oyun kullanımı ile aile iletişim boyutlarının kadın katılımcılara göre daha olumsuz yönde etkilendiği ve bu nedenle ölçek puanlarının kadınların puanlarından anlamlı düzeyde yüksek olduğu görülmüştür. Erkeklerin oyun oynama sürelerinin kadınlardan daha fazla olması bu sonuçta etkili olmuş olabilir. "Bilgisayar oyunu oynamıyorum" ifadesini belirten erkek katılımcıların oranı yaklaşık \%4 iken, bu oran kadınlarda yaklaşık \%55'tir. Mobil oyunlarda ise oyun oynamadığını belirten erkek katılımcıların oranı yaklaşık \%10 iken, kadın katılımcılarda ise bu oran yaklaşık \% 47 'tir. Erkek katılımcıların kadınlara göre daha fazla dijital oyun oynamaya eğilimli olmaları mevcut alanyazın araştırmaları ile örtüşmektedir (Dursun, Erarslan-Çapan, 2018; Eryılmaz ve Çukurluöz, 2018; Horzum, 2011; Kılıç, 2019; Li ve Wang, 2013; Mustafaoğlu ve Yasac1, 2018; Soyöz-Semerci ve Balc1, 2020; Şahin ve Tuğrul, 2012).

Üniversite öğrencilerinin oynadıkları dijital oyun türlerinin de incelendiği çalışmada en çok oynanan oyunlar sırasıyla "Counter Strike", "LoL" ve "PUBG" oyunları olmuştur. Tercih sıralamasına göre ise; "LoL" ve "Counter Strike" ilk sıralarda yer alan oyunlardır. Mobil oyunlarda ise en fazla oynanan oyun siralaması; "PUBG", "LoL", "Candy Crush" ve "Clash Royale" olmuştur. Tercih sıralamasında ilk sırada olma durumuna göre "PUBG", "LoL" ve "Clash Royale" olarak sıralama gerçekleşmiştir. Cinsiyete göre bilgisayar oyun tercihleri incelendiği zaman kadınların tercih sıralaması; "LoL", "PUBG" ve "GTA5" 
olurken, erkek katılımcıların ise; "Counter Strike", "LoL” ve "Grand Theft Auto" şeklinde olmuştur. Mobil oyunlarda ise kadınların tercih sıralaması; "PUBG", "Candy Crush" ve "Among Us" / "Kafa Topu 2" / "LoL" olurken, erkek katılımciların ise; "PUBG", "LoL" ve "Clash Royale" olmuştur. Üniversite öğrencilerinin oyun tercihlerine yönelik gerçekleştirilen Bekir (2018)' in çalışması ile uyumluluklar göstermektedir. Bekir (2018) 380 üniversite öğrencisinin katıldığı çalışmasında, katılımcıların \%31,6'sının "LoL", \%29,7'sinin “Counter Strike”, \%7,6'sının “PUBG” oyunlarını tercih ettiğini belirlemiştir.

Elde edilen sonuçlara göre; katılımcılar bilgisayar, mobil cihazlar ve bu cihazlarında yer alan oyun uygulamalarına oldukça zaman ayırmaktadırlar. Dijital cihazlar ile geçirilen süre onların farklı uygulamalara yönelik bağımlılık durumlarına tetikleyici olabilir. Ergin ve ark. (2013) tarafından 386 üniversite öğrencisinin katılımı ile gerçekleştirilen çalışmada; internet bağımlısı veya riskli kullanıcı olma sıklığının, haftalık internet kullanım süresiyle pozitif ilişkili olduğu sonucuna ulaşmışlardır. $\mathrm{Bu}$ nedenle kişilerin özdenetim sistemlerinin gelişmiş olması, kendilerinin bağımlı olmalarında etkili olabilir. Bu özdenetim sisteminin gelişmesinde hem ailesinden erken yaşlarda alacağ 1 eğitim, hem de örgün ve yaygın eğitim kapsamında alabileceği medya okur yazarlığı eğitimlerinin faydası olabilir. Eğitim öğretim yaşantısının temelinin atıldığı aile hayatı da büyük önem taşımaktadır. Aile büyüklerinin örnek davranışlarla model olması ve çocuklarına uygun tutum geliştirmeye yönelik yönlendirmeler yapmaları önemlidir. Bu süreçte de ailenin farklı başlıklarda eğitimler almaları gerekebilmektedir. Anne babaların teknolojik gelişmeler neticesinde yaşanabilecek olumsuzluklara ilişkin yeterli düzeyde bilgi sahibi olduklarını söylemek oldukça zordur. Yiğit ve Günüç (2020) anne ve babaların dijital oyun bağımlılığı özelinde bilgi düzeylerini araştırdıkları çalışmalarında; velilerin teknolojinin olumsuz etkileri hakkında bilgili olduklarını fakat teknoloji kullanımının yol açtığı olumsuz etkiler karşısında çocuklarını yönlendirme konusunda kendilerini yetersiz hissettiklerini ve çocuklarını yasaklama yolunu tercih ettiklerini belirlemişledir. Bu çalışmada ayrıca anne babalar çocuklarının dijital oyun bağımlısı olma nedeni olarak, okul ve arkadaş çevresinin etkili olduğunu belirtmişlerdir. Kırık (2014) tarafından yapılan başka bir çalışmada ebeveynlerin yarısı, çocukları internette zaman geçirirken onları takip etmek yerine, bu süreçte kendi işleriyle meşgul olduklarını ifade etmişlerdir. Ayrıca ebeveynlerin çoğunluğunun internetin olumsuz etkilerine karşı çözüm aramadıklarını, çocukları korumak için gerekli önlemleri almadıkları aynı çalışmada belirlenmiştir. Tutarsız, yasaklayıcı, aşırı denetleyici ve ihmalkâr veli davranışları, çocuklarda istendik davranış değişikliklerinin yaratılmasında etkili olmayabilir. Hatta bu davranış biçimleri ergenlerde güvensizlik ve kuşku yaratarak, onların anti sosyal, suça yönelik ve çelişkili davranışlar içerisinde bulunmasına neden olabilir (İnanç, 2005). Ayas ve Horzum (2013) yaptıkları çalışmada ihmalkâr tutum gösteren ailelerde yetişen çocukların; otoriter, müsamahakâr ve demokratik tutum gösteren ailelerde yetişen çocuklara oranla daha fazla internet bağımlısı olduğu sonucuna ulaşmışlardır. Ayrıca gençler aile iletişiminde olumsuzluklar yaşadıklarında dijital bağımlılık dışında olumsuz arkadaşlıklar kurabilmekte; farklı madde kullanım bağımlılıklarına yönelebilmektedir (Gül ve Güneş, 2009). Bu nedenle aile iletişimi diğer bağımlılıklarda olduğu gibi dijital oyun bağımlılığında önemlidir. Dolayısıyla dijital oyun bağımlılı̆̆ı tedavisinde benzer bir yaklaşım olan aile terapisi de kullanılmaktadır (Arısoy, 2009; Bekar, 2018). Ayrıca aile ile geçirilen sürenin oyun 
bağımlılığında iyileşmeye yol açabileceğine yönelik çalışmalar vardır (Han ve ark., 2012). Bu nedenle ailelerin çocukları ile samimi bir diyalog ortamı kurması, çocukların dijital araç gereçlerle oynamalarına yönelik tutarlı tutumlar sergileyerek dijital ebeveynlik bilinç düzeylerini ortaya koyabilmeleri gerekmektedir (Kaya, Bayraktar \& Y1lmaz, 2018). Bunun içinde ailelerin mutlaka farklı görsel ve işitsel medya platformlarından da yararlanılarak eğitimler ve seminerler almaları önem taşımaktadır. Bu eğitimlerde, farklı yaş dönemlerinde dijital oyun başta olmak üzere, farklı dijital platformların kullanımına yönelik ne tür önlemler alınabileceğine yönelik bilgiler verilebilir.

Ortaokullarda 5. ve 6. Sınıf seviyelerinde "Bilişim Teknolojileri” dersi zorunlu bir ders olarak verilmektedir. Fakat lise seviyesinde herhangi bir ders zorunluluğu bulunmamaktadır. Oysaki akademik başarının düşmesinde maalesef dijital ekran uygulamalarına yönelik bağımlılık ve uzun süre kullanımlarının olumsuz etkileri bulunmaktadır. Sadece küçük yaş gruplarını değil, büyük yaş gruplarını da akademik açıdan olumsuz yönde etkileyebilmektedir. Örneğin Bülbül, Tunç ve Aydil (2018) dijital oyun bağımlılığı ile üniversite öğrencilerin ders çalışma sürelerinin azaldığı ve akademik başarı düzeylerinin düştüğü sonucuna ulaşmıştır. $\mathrm{Bu}$ nedenle lise seviyesinde ders içeriklerinde "Güvenli İnternet ve Dijital Ekran Uygulamalarının Sağlıklı Kullanımı" kapsamında konuların da yer aldığı dersler verilebilir.

\section{Kaynaklar}

Arısoy, Ö. (2009). İnternet bağımlılı̆̆ı ve tedavisi. Psikiyatride güncel yaklaşımlar, 1(1), 55-67.

Ayas, T., \& Horzum, M. B. (2016). İlköğretim öğrencilerinin internet bağımlılı̆̆1 ve aile internet tutumu. Turkish Psychological Counseling and Guidance Journal, 4(39), 46-57.

Ayas T, Horzum M.B. (2017). Teknolojinin olumsuz etkileri. Vize Yayıncıllk: Ankara.

Bekar, T. (2018). Üniversite öğrencilerinde teknoloji ile ilgili bağımlılıklar ve ilişkili faktörler. Yayımlanmamış Uzmanlık Tezi, Pamukkale Üniversitesi Tıp Fakültesi, Halk Sağlığı Anabilim Dalı, Denizli.

Bekir, S. (2019). Üniversite öğrencilerinde çevrimiçi oyun bağımlılı̆̆ı düzeyinin duygusal şemalar, eylemli kişilik ve bazı değişkenler açısından incelenmesi. Yayımlanmış Yüksek Lisans Tezi, Sakarya Üniversitesi Eğitim Bilimleri Enstitüsü, Sakarya.

Bonnaire, C., \& Phan, O. (2017). Relationships between parental attitudes, family functioning and Internet gaming disorder in adolescents attending school. Psychiatry Research, 255, 104-110.

Bülbül, H., Tunç, T., \& Aydil, F. (2018). Üniversite öğrencilerinde oyun bağımlılığı: Kişisel özellikler ve başarı ile ilişkisi. Ömer Halisdemir Üniversitesi İktisadi ve İdari Bilimler Fakültesi Dergisi, 11(3), 97-111. 
Çavuş, S., Ayhan, B., \& Tuncer, M. (2016). Bilgisayar oyunları ve bağımlılık: Üniversite öğrencileri üzerine bir alan araştırması. İletişim Kuram ve Araştırma Dergisi, (43), 265-289.

Çelik, E. (2018). Öğretmenlerin internet, sosyal medya bağımlılıkları ile evlilikte uyum ve aile işlevleri arasındaki ilişki. Yayımlanmamış Yüksek Lisans Tezi, İstanbul Sabahattin Zaim Üniversitesi, Sosyal Bilimler Enstitüsü, Aile Danışmanlığı ve Eğitimi Anabilim Dal, İstanbul.

Demir, Ü. (2016). Sosyal medya kullanımı ve aile iletişimi: Çanakkale'de lise öğrencileri üzerine bir araştırma. Selçuk İletişim Dergisi, 9(2), 27-50.

Dilber, F. (2019). Aile İçi İletişimde Sosyal Medya: Karamanoğlu Mehmetbey Üniversitesi Öğrencileri Üzerine Bir Araştırma. Adıyaman Üniversitesi Sosyal Bilimler Enstitüsü Dergisi, (33), 334-381.

Dursun, A. Eraslan-Çapan, B. (2018). Ergenlerde Dijital Oyun Bağımlılığı ve Psikolojik İhtiyaçlar. İnönü Üniversitesi Eğitim Fakültesi Dergisi, 19(2), 128-140.

Eni, B. (2017). Lise Öğrencilerinin Dijital Oyun Bağımlılığı ve Algıladıkları Ebeveyn Tutumlarının Değerlendirilmesi. Yayımlanmamış Yüksek Lisans Tezi, HaliçÜniversitesi/ Sosyal Bilimler Enstitüsü, İstanbul.

Ergin, A., Uzun, S. U., \& Bozkurt, A. İ. (2013). Tıp fakültesi öğrencilerinde internet bağımlılığı sıklığı ve etkileyen etmenler. Pamukkale Tıp Dergisi, (3), 134-142.

Eryılmaz, S., \& Çukurluöz, Ö. (2018). Lise Öğrencilerinin Dijital Bağimliliklarinin İncelenmesi: Ankara İli, Çankaya İlçesi Örneği. Elektronik Sosyal Bilimler Dergisi, 17(67), 889-912.

Griffiths, M. D. (2008). Internet and Video-Game Addiction. Adolescent Addiction: Epidemiology, Assessment and Treatment, 231-267, Academic Press.

Gül, S. K., \& Güneş, İ. D. (2009). Ergenlik Dönemi Sorunlari Ve Şiddet. Sosyal Bilimler Dergisi, 11(1), 80.

Güleç, V. (2018). Aile ilişkilerinin sosyal medyayla birlikte çöküşü. Yeni Medya Elektronik Dergisi, 2(2), 105-120.

Gülbetekin, E., Güven, E., \& Tuncel, O. (2021). Adolesanların Dijital Oyun Bağımlılığı ile Fiziksel Aktivite Tutum ve Davranışlarını Etkileyen Faktörler. Bağımlılık Dergisi, 22(2), 148-160.

Gümüş, A. B., Şıpkın, S., Tuna, A., \& Keskin, G. (2015). Üniversite öğrencilerinde problemli internet kullanımı, şiddet eğilimi ve bazı demografik değişkenler arasındaki ilişki. TAF Preventive Medicine Bulletin, 14(6), 460-467.

Han, D. H., Kim, S. M., Lee, Y. S., \& Renshaw, P. F. (2012). The effect of family therapy on the changes in the severity of on-line game play and brain activity in adolescents with on-line game addiction. Psychiatry Research: Neuroimaging, 202(2), 126-131. 
Horzum, M. B. (2011). İlköğretim Öğrencilerinin Bilgisayar Oyunu Bağımlılık Düzeylerinin Çeşitli Değişkenlere Göre İncelenmesi. Eğitim ve Bilim, 36(159), 56-68.

Kacaoğlu, D. (2019). Çocuklarda bilgisayar oyun bağımlılı̆̆ ile aile ilişkileri arasındaki ilişkinin incelenmesi. Yayımlanmamış Yüksek Lisans Tezi, Sabahattin Zaim Üniversitesi, Sosyal Bilimler Enstitüsü, Eğitim Bilimleri Anabilim Dalı, İstanbul.

Karaçor, S., \& Şahin, A. (2004). Örgütsel İletişim Kurma Yöntemleri Ve Karşilaşilan İletişim Engellerine Yönelik Bir Araştirma. Sosyal Ekonomik Araştırmalar Dergisi, 4(8), 96-117.

Karasar, N. (2007). Bilimsel araştırma yöntemleri (17. baskı). Ankara: Nobel Yayıncilik.

Kaya, G. İ., Bayrakdar D. M., \& Yılmaz, Ö. (2018). Dijital ebeveynlik tutum ölçeği: geçerlik ve güvenirlik çalışması. Mehmet Akif Ersoy Üniversitesi Eğitim Fakültesi Dergisi, (46), 149-173.

Kılıç K. M. (2019). Ergenlerde dijital oyun bağımlılığı, zorbalık bilişleri ve empati düzeyleri arasındaki ilişkiler. Elementary Education Online, 18(2), 549-562.

Kwon, J. H., Chung, C. S., \& Lee, J. (2011). The effects of escape from self and interpersonal relationship on the pathological use of Internet games. Community mental health journal, 47(1), 113-121.

Li, H., \& Wang, S. (2013). The role of cognitive distortion in online game addiction among Chinese adolescents. Children and youth services review, 35(9), 1468-1475.

Mustafaoğlu, R., \& Yasacı, Z. (2018). Dijital oyun oynamanın çocukların ruhsal ve fiziksel sağlığı üzerine olumsuz etkileri. Bağımlılık Dergisi, 19(3), 51-58.

Ni, X., Yan, H., Chen, S., \& Liu, Z. (2009). Factors influencing internet addiction in a sample of freshmen university students in China. Cyberpsychology \& behavior, 12(3), 327-330.

Okumuş, V., \& Parlar, H. (2018). Çocukların sosyal medya kullanım amaçları ve ebeveyn tutumları. İstanbul Ticaret Üniversitesi Sosyal Bilimler Dergisi, 17(33), 357368.

Özkan, A., \& Hira, İ. (2017). Dijital medya ve sosyalleşme: 6-12 yaş çocukların sosyalleşmesine dair ebeveyn görüşleri (İstanbul Örneği). Kesit Akademi Dergisi, 3(9), 245-270.

Soyöz-Semerci, Ö. U. ve Balcı, E. V. (2020). Lise öğrencilerinde dijital oyun bağımlılığı üzerine bir alan araştırması: Uşak örneği. Journal of Humanities and Tourism Research, 10(3), 538-567.

Şahin, C., \& Tuğrul, V. M. (2012). İlköğretim öğrencilerinin bilgisayar oyunu bağımlılık düzeylerinin incelenmesi. Zeitschrift für die Welt der Türken/Journal of World of Turks, 4(3), 115-130. 
Toran, M., Ulusoy, Z., AYDIN, B., Deveci, T., \& Akbulut, A. (2016). Çocukların dijital oyun kullanımına ilişkin annelerin görüşlerinin değerlendirilmesi. Kastamonu Eğitim Dergisi, 24(5), 2263-2278.

Turan, R. T. (2015). Başkent Üniversitesi öğrencilerinde internet bağımlılı̆̆ 1 sıklı̆̆ ve ilişkili faktörler. Yayımlanmamış Yüksek Lisans Tezi, Başkent Üniversitesi, Ankara.

Usta, M. (2019). Aile İşlevselliğinin Psikolojik İhtiyaçları Karşılamadaki Rolü. Aile Psikolojik Danışmanlığı Dergisi, 2(2), 1-20.

Ülker Ü, Acar S, Bülbül H.İ. (2017). Lisansüstü Öğrencilerin Eğitsel Dijital Oyunların Eğitim Amaçlı Kullanılmasına Yönelik Görüşleri. 11. Uluslararası Bilgisayar ve Öğretim Teknolojileri Sempozyumu Kitabı, 111-118.

Yiğit, E., \& Gününç, S. (2020). Çocukların dijital oyun bağımlılığına göre aile profillerinin belirlenmesi. Yüzüncü Yıl Üniversitesi Eğitim Fakültesi Dergisi, 17(1), 144174.

Zhu, J., Zhang, W., Yu, C., \& Bao, Z. (2015). Early adolescent Internet game addiction in context: How parents, school, and peers impact youth. Computers in Human Behavior, 50, 159-168.

Destekleyen Kurum/Kuruluşlar: Herhangi bir kurum/kuruluştan destek alınmamıştır.

Çıkar Çatışması: Herhangi bir çıkar çatışması bulunmamaktadır. 